\title{
Food waste management - Survey on current trends around Erode, Tamil Nadu.
}

\author{
M. Ajeeth Pandian ${ }^{1 *}$, S. Saranya ${ }^{1}$, R. Lakshmi Rathi ${ }^{1}$, G. Kiruthika ${ }^{\mathbf{1}}$, S. Anita ${ }^{\mathbf{1}}$ \\ ${ }^{1}$ Department of Food Technology, K. S. Rangasamy College of technology, Tiruchengode, Namakkal District, Tamil \\ Nadu, India. \\ *Corresponding author E-Mail ID: rlmmurugu@gmail.com
}

Doi: https://doi.org/10.34256/irjmtcon52

\begin{abstract}
Food waste plays an important role in the economy of food sectors. Apart from direct implication of feeding the needy, decreasing food waste would lead to improved land utilization and water resources management. This article is meant to bring out the food waste management practices followed in and around Erode, Tamil Nadu, and India. The study is based on surveying methodology conducted by designing a questionnaire to bring out the current methods practiced for food waste disposal in restaurants in the locality. The finding of the survey implicates a considerable reduction in the use of plastics following the ban on single use plastics through a government order.
\end{abstract}

Keywords: Waste management, Food packaging, Alternatives, Environmental sustainability, Surveying.

\section{INTRODUCTION}

India is one of the largest quantities of food producer for last five decades. India tops the production of milk, fruits, vegetables and grains in the world. Yet due to poor post harvest management and inadequate infrastructural facilities and technology, India is one of leading country in production of waste. In India, the amount of waste generated per capita is estimated to increase at a rate of 1 to $1.33 \%$ annually.

Waste is any undesirable, unwanted substance which is to be discarded or intended to be discarded material left over after the completion of a certain process. In general, food waste are biodegradable waste (Paritosh et al., 2017) discharged from various food processing units mainly fruits and vegetable processing, cereals and grain processing, dairy industries, fish, meat and poultry processing units.

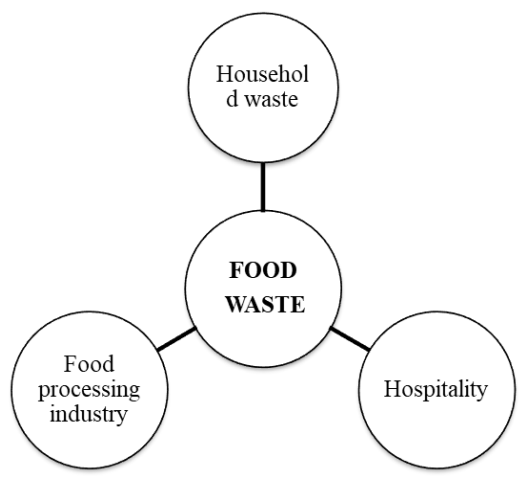

Fig 1: Sources of food waste 
These food wastes may be generated in every stage of food processing including undesirable or spoiled raw material, mishandling of equipments, spill, improper storage and delay in marketing or consumption Papargyropoulou et al (2014). In addition, the wastes from household and hospitality sectors are categorized under the food waste (as shown in Fig1). The hotel waste can be wet waste or dry waste. The wet waste comprises of vegetable, waste from non-vegan food and waste water. The papers, plastic wrappers and bags are placed under the dry waste of hotel industries. The major factors contributing to the food waste generation are urbanization, lifestyle pattern, excessive food production, improper handling and storage.

The food waste generation and disposal is one of the important issues at in developing countries of Asia including India. Besides causing economic losses, they also have a great impact on the environment. The Central Pollution Control Board had reported that the pollution problems in food sector are mainly due to the wastewater and solid waste generated during production. The process of heating, boiling and any other process that involves steam are one of the major threats of air pollution. Also, the particulate emissions from burning of fuels cause air pollution. When the wash water or water from CIP and water after processing are disposed without treatment, they pollute the water bodies. There may be variations in BOD, COD and $\mathrm{pH}$ altering the quality of water. The untreated waste may act as a substrate for the growth of harmful microbes thereby making it unfit for aquatic survival and human consumption.

The choice of disposal method determines the extent of environmental pollution. According to Tamilnadu Pollution Control Board, there are 12 corporations, 124 municipalities and 528 town panchayats. The total quantity of solid waste generated is approximately 1.5 MT/day, of which $98 \%$ of municipal solid waste is being collected, $32 \%$ of solid waste is being treated and more than $50 \%$ of solid waste is land-filled in the landfill sites located in the state of Tamil Nadu.

In general, the disposal of food wastes involves the composting, vermicomposting, animal feed production, pit disposal, landfill and incineration. Some of the hotel industries contribute the excess food to local communities. The simplest method of on-site disposal method is pit disposal which does not require any transportation or special design. Even though they are economical, they may turn the place unhygienic.

The off-site disposal methods include composting, vermicomposting, animal feed production, landfill and incineration. Landfill is one of the most commonly used methods of disposal. Unlike pit disposal, the place of disposal is located far from the hotels so as to maintain good hygiene and sanitation. The major problem with the landfill is the use of larger area.

Incineration, also known as burning, involves combustion of waste. This method can be implemented only if the wastes generated are combustible. They are incinerated in pits and covered with soil after burning. Burning may be used to reduce the volume of the waste and may be appropriate when there is limited space for land filling or burial. The major constraint is the smoke or fire hazards produced on incineration of wastes.

Composting and vermi-composting are eco-friendly methods of disposal for organic food wastes. They involve biological decomposition of organic materials by digging into soil and composting to add humus and enrich the soil. In case of vermicomposting, the process of composting is carried out by the earthworms. These methods not only minimize waste but also add fertility to the soil. These methods require intensive management and experienced personnel. The food scraps from the hotels are collected by local farmers on free of cost or at nominal cost to feed the animals. This method could not be used on regular basis since the requirement or demand for animal feed may vary.

In addition, some of the hotels an aerobically digest the food waste for biogas production. The anaerobic digestion process yields methane which can be used as a fuel for combustion. 
Studies have reported that the pre-treatment of food waste with bead mill, microwaves and other chemical treatments increase the efficiency and yield of biogas ([8], [9] \& [10]).

\section{MATERIALS AND METHODS}

\section{A. Survey methodology}

Both qualitative and quantitative methods were employed in this survey. Restaurants around Erode were selected for participating in the survey. The number of participants was empirically decided as 10 . The randomly selected restaurants were assured of their willingness to participate in the survey. A detailed questionnaire to capture allthe aspects of waste management methods was designed. It consists of two major categories: i) the first one dealt with the amount of solid waste generated in restaurants and ii) the second one dealt with the methods of disposal followed by the restaurants

\section{B. Survey questionnaire}

Name of the restaurant:

Contact person:

Designation:

Address for communication:

Voluntary consent: I undertake this survey purely based on my interest to understand the waste management status of my restaurant. I authorize that the data collected can be used for scientific publications.

Signature:

Survey questions:

1) What is the total amount of generated per day (in $\mathrm{kg}$ )?
a. Solid food waste
b. Liquid food waste
c. Semi - solid food waste

2) What is the total amount of waste generated per day (in $\mathrm{kg}$ ) from
a. Served plates
b. Excess production

3) What is the total amount of raw material waste generated per day (in $\mathrm{kg}$ )?

(For example. Vegetable peels)

4) What is the total amount of garden waste generated per day (in $\mathrm{kg}$ )?

5) What is the total amount of other waste generated per day (in $\mathrm{kg}$ )?
a. Paper waste (tissues,cups,plates,straw)
b. Plastics (cups,packs,spoon)
c. Other(s) (if any specify)

6) Do you categorize waste into biodegradable and non biodegradable?

7) How do you dispose the food waste generated? 
8) How do you dispose the non- biodegradable waste?

9) How do you dispose the biodegradable waste?

10) How do you dispose the paper waste and plastic waste?

11) Do you dispose waste on regular interval of time or on weight basis? If so frequency.

12) Do you have separate team for waste disposal and management?

13) Are you aware of government and NGOs role in waste management?

14) How are you implementing 4R's of waste management in your restaurant?

15) Do you have a special budget dedicated for waste management? If yes, specify in $\%$.

\section{Data analysis}

A master spread sheet consisting of all the parameters addressed was prepared. The quantitative data was converted into their relative percentages for better understanding. Plots and graphs were created for pictorial representation of the data.

\section{RESULTS AND DISCUSSION}

\section{A. Categorization of solid waste from restaurants}

Based on the data collected, the total amount of solid and semi-solid waste generated from 10 restaurants in the locality is about $355 \mathrm{~kg}$ with an average of $35 \mathrm{~kg}$ per day per restaurant. Food waste from served plates and excess food wasted without consumption constitute a major proportion of total waste adding to about $70 \%$. Wastes from precooked food such as vegetable peels constitute $21 \%$. Garden and paper wastes constitute $3 \%$ each with plastic waste constituting about $3 \%$.

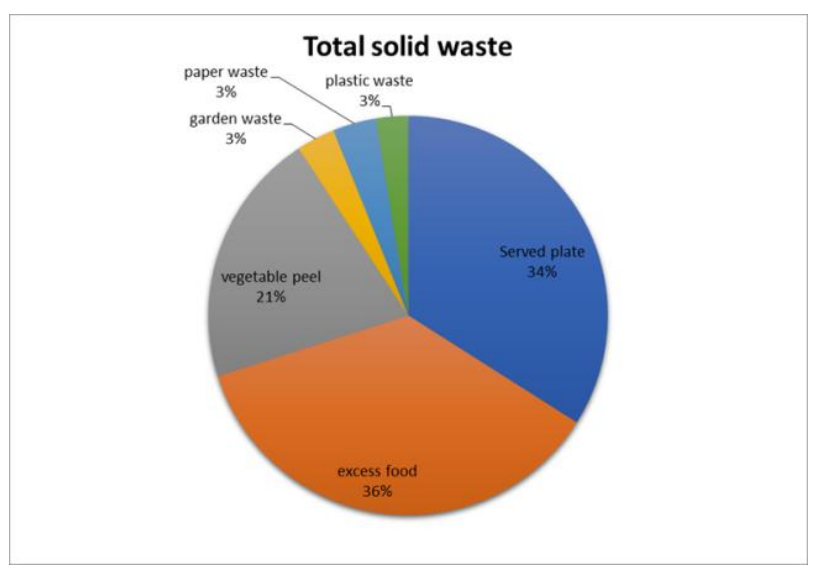

Fig 2: Categorization of total solid waste disposed at restaurants in the locality.

There is a considerable improvement in the amount of waste generated as far as plastic waste is concerned. The state has imposed partial ban on the use of plastic commodities. The disposable plastics are totally banned throughout the state. Any consumer or retailer found using/selling single use plastics are punishable as per the G.O. (Ms). No.84 dated 25.06.2018. It imparts a ban on manufacture, store, supply, transport, sale or distribute of use and throwaway plastics, plastic sheets used for food wrapping, spreading on dining table etc., plastic plates, plastic coated tea cups and plastic tumbler, water pouches and packets, plastic straw and plastic carry bag irrespective of thickness. Sustainable alternatives to replace the use of disposable plastics are under development. 


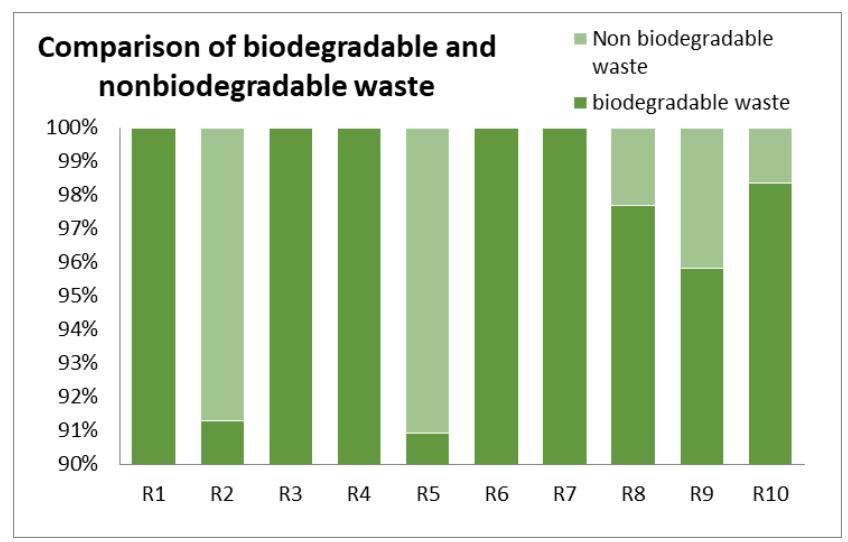

Fig 3. Comparison of biodegradable and non-biodegradable waste.

From the fig 3, we could see that the amount of non-biodegradable waste is very minimal from all the 10 restaurant surveyed. It is almost nil for $50 \%$ of restaurant. The amount of nonbiodegradable waste from other half of restaurants was less than $10 \%$ of total waste generated. Hence food restaurant sectors contribute a very minimal amount of plastic waste after the enforcement of GO on the ban of single use plastic. Take away restaurants are not surveyed as a part of this study, hence relating this data to all food sector is not feasible.

The major contribution of plastic ban is on the source reduction. Reuse is encouraged through the use of steel and porcelain cutlery. The minimum thickness of single use plastic is changed from 40 micron to 50 micron. Hence the cost of production is expected to increase to about $20 \%$ [11]. This will bring down the tendency of issuing free carry bags and it expected to reduce the use of single use plastics drastically. The plastic waste management rules [11] states that the single use plastics should be recycled based on the thickness of plastic material Nonrecyclable plastic materials should be employed in road constructions as per Indian Road Congress guidelines.

\section{B. Methods of waste management}

There are several methods followed for managing waste from food sources. The basic 4Rs such as reduction, reusing, recycling and recovery could be applicable to food waste management. Of all the restaurants surveyed, a majority of them $(50 \%)$ hand over the food waste to municipality personnel who collect the solid waste at the door steps. The remaining $50 \%$ of the restaurants have their own ways of managing wastes. They either use it as a cattle feed (particularly vegetable peels and cooked food waste) or use it for composting which they use it in their cultivatable lands. About $10 \%$ of the restaurants incinerate the non-biodegradable solid wastes.

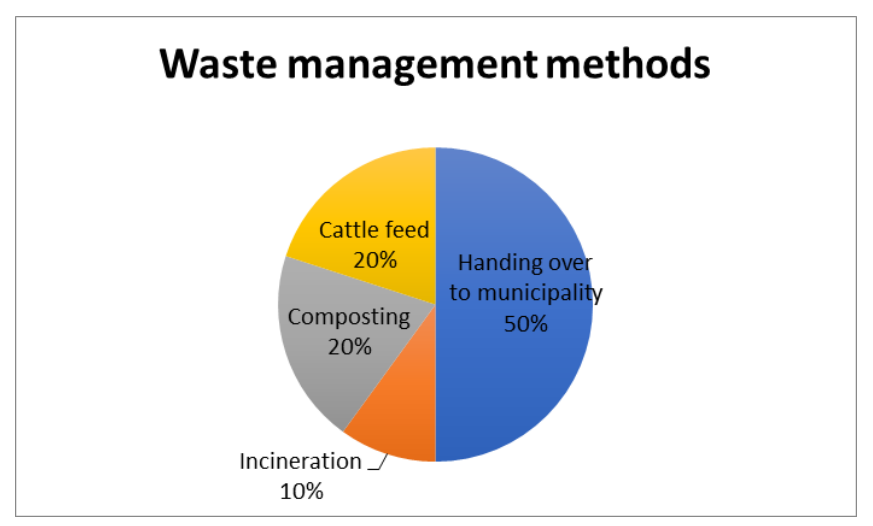

Fig 4. Waste management methods followed by restaurants around Erode, Tamil Nadu. 
Reference [7] reported the classification of food waste generated in hospitality industry. This current study is found to correlate with the findings. For a country as populated as India, food waste is considered evil. There are a large number of people who struggle to find food to satisfy their hunger. Hence, a proper channel should be arranged to enable food waste to reach the required personnel. Some of the NGOs around Erode were found to do the same.

$20 \%$ of restaurants use their waste as cattle feed. Hence the animals might get benefitted. With less amount of grazing food available for cattles, food products and wastes including vegetable peels provide an excellent alternative for food needs. $20 \%$ of the restaurants use the food waste for composting. They generate their own compost, which they either sell it to agriculturists or use it for their own farms.

\section{Special budget dedicated for waste management}

Most of the restaurants surveyed had a dedicated budget for food waste management. Few restaurants had no idea about the amount dedicated for waste disposal expenses, hence reported it as $0 \%$. However they confirmed that they have no account maintained for calculating expenses dedicated for waste disposal.

Table 1. Special budget dedicated for waste management

\begin{tabular}{|c|c|}
\hline Restaurants & $\begin{array}{c}\text { Special budget for } \\
\text { waste disposal }\end{array}$ \\
\hline R1 & $0.5 \%$ \\
\hline R2 & $0.1 \%$ \\
\hline R3 & $0.3 \%$ \\
\hline R4 & $0.0 \%$ \\
\hline R5 & $0.2 \%$ \\
\hline R6 & $1.0 \%$ \\
\hline R7 & $0.0 \%$ \\
\hline R8 & $0.2 \%$ \\
\hline R9 & $0.7 \%$ \\
\hline R10 & $0.0 \%$ \\
\hline
\end{tabular}

The disposal cost include transportation of waste to land filling location, landfilling charges as per local municipal bodies, charges associated with employment of trash collectors and efficient cleaning systems.

\section{CONCLUSIONS}

The food waste management methods were identified in the selected locality. The amount of food waste generated for a restaurant is almost $35 \mathrm{~kg} /$ day. It included both solid and semi-solid wastes. The waste management systems are already in place. Most of the restaurants surveyed send their total waste in a frequency of one - two days to garbage collection centers in the locality. Few restaurants have their own disposal methods such as animal feeds, composting and incineration. The study helped in understanding the mindset of consumers in avoiding the use of plastics especially after the ban proposed. Several food waste reduction methods can be introduced such as displaying food waste tracking sheets, awareness charts on food wastage and placing a separate containers to accumulate the food wasted to be utilized for needy people could bring about a change in people mindset.

\section{REFERENCES}

1. A. Gallego-Schmid, J. M. F. Mendoza and A. Azapagic, "Environmental impacts of takeaway food containers," Journal of Cleaner Production, vol. 211, pp. 417-427, Feb. 2019. 
2. Advancing Sustainable Materials Management: 2015 Fact Sheet, Assessing Trends in Material Generation, Recycling, Composting, Combustion with Energy recovery and Landfilling in the United States, United States Environmental Protecion Agency, Jul. 2018.

3. Annual Report (2017 - 2018) by Tamil Nadu State Pollution Control Board - Submitted to Central Pollution Control Board, Form V.

4. D. Kirk, Environmental Management for Hotels - A Student's Handbook, ButterworthHeinemann, 1996

5. D. N. Trung and S. Kumar, "Resource use and waste management in Vietnam hotel industry," Journal of Cleaner Production, vol. 13, pp. 109-116, 2005.

6. E Papargyropoulou, R. Lozano, J. K. Steinberger, N. Wright and Z. Ujang, "The food waste hierarchy as a framework for the management of food surplus and food waste," Journal of Cleaner Production, vol. 76, pp. 106-115, Aug. 2019.

7. E. Pauer, B. Wohner, V. Heinrich and M. Tacker, "Assessing the Environmental Sustainability of Food Packaging: An Extended Life Cycle Assessment including Packaging-Related Food Losses and Waste and Circularity Assessment," Sustainability, vol. 11(3), pp. 925, Feb. 2019.

8. G. Mahesh Kumar, A. Irshad, B.V. Raghunath and G. Rajarajan, "Waste Management in Food Packaging Industry," Integrated Waste Management in India, Environmental Science and Engineering, pp. 265-277, 2016.

9. J. Ma, T. H. Duong, M. Smits, W. Verstraete, and M. Carballa, "Enhanced biomethanation of kitchen waste by

10. K. Izumi, Y. K. Okishio, C. Niwa, S. Yamamoto, and T. Toda, "Effects of particle size on anaerobic digestion of food waste," International Journal of Bio-Deterioration Biodegradation, vol. 64, no. 7, pp. 601-608, 2010.

11. K. Marsh, B. Bugusu, "Food Packaging-Roles, Materials, and Environmental Issues," Journal of Food Science, Vol. 72(3), pp. 39-55, Apr. 2007.

12. K. Paritosh, S. K. Kushwaha, M. Yadav, N. Pareek, A. Chawade and V. Vivekanand, "Food Waste to Energy: An Overview of Sustainable Approaches for Food Waste Management and Nutrient Recycling," BioMed Research International, vol. 2017, Article ID 2370927, 19 pages, Feb. 2017.

13. M. Sharholy, K. Ahmad, G. Mahmood and R. C. Trivedi, "Municipal solid waste management in Indian cities - A review," Waste Management, vol. 28(2), pp. 459-467, Apr. 2012.

14. Plastic Management Rules 2016, Tamil Nadu Pollution Control Board.

15. Plastic waste management rules 2018, Press Information Bureau, Government of India, Ministry of Environment, Forest and Climate Change, Mar. 2018.

16. Qualitative research study performed on fighting food waste in Hotels by Bellinson\& Company, 2016.

17. S. I. Pirani and H. A.Arafat, "Reduction of food waste generation in the hospitality industry," Journal of Cleaner Production, vol. 132, pp. 129-145, Sep. 2016.

18. T. A. Trabold and V. Nair, Sustainable Food Waste-to-Energy Systems, Academic Press, pp. 29-45, 2018. 